\title{
Colonic Acetate in the Circulating Acetate Pool of the Infant Pig ${ }^{1}$
}

\author{
KATHARINE FREEMAN, THOMAS FOY, ANDREW S. FESTE, PETER J. REEDS, AND \\ CARLOS H. LIFSCHITZ \\ USDA/ARS Children's Nutrition Research Center, Department of Pediatrics, Baylor College of Medicine, \\ Houston, Texas 77030
}

\begin{abstract}
To identify potential sites of acetate utilization and synthesis, we studied the contribution of colonic acetate to the circulating acetate pool in six neonatal pigs by the simultaneous i.v. infusion of $\left[{ }^{3} \mathrm{H}\right]$ acetate and colonic infusion of $\left[{ }^{14} \mathrm{Clacetate}\right.$. In the fasting state, the mean $( \pm$ SEM) acetate concentration was $17 \pm 1 \mu \mathrm{mol} / \mathrm{L}$ in peripheral venous blood, $28 \pm 4 \mu \mathrm{mol} / \mathrm{L}$ in the femoral artery, and $46 \pm 4 \mu \mathrm{mol} / \mathrm{L}$ in portal blood. This concentration gradient implies that acetate was utilized either by peripheral tissues alone or by both liver and peripheral tissues. At the end of the 2-h intracecal acetate infusion, mean acetate concentration increased in the femoral artery to $186 \pm 20 \mu \mathrm{mol} / \mathrm{L}$ and in the portal vein to $333 \pm 31 \mu \mathrm{mol} /$ L. In the fasted state, mean acetate concentration in the portal vein was on average $63 \%$ higher than the acetate concentration of the femoral artery, whereas specific radioactivity of the $\left[{ }^{3} \mathrm{H}\right]$ acetate in the portal vein was only $5 \%$ of that in the femoral artery. It is possible, therefore, that a high proportion of the arterial input of acetate is utilized by the portal-drained viscera. Our study identified the gastrointestinal tract as an important site of acetate utilization in the fasted state. Further, it showed that colonic acetate was efficiently absorbed and utilized in the gastrointestinal tract of infant pigs. (Pediatr Res 34: 318-322, 1993)
\end{abstract}

In humans, most short-chain fatty acids (acetate, propionate, and butyrate) produced by colonic bacteria are fermentation products of the dietary carbohydrates that escaped digestion in the small intestine (1). Short-chain fatty acids are the principal anions in the colon and are important in water and electrolyte transport and in maintenance of the colonic milieu (2-3). Direct and indirect evidence indicates that short-chain fatty acids play an important role in the nutrition of the cells lining the large bowel of humans (4-6).

Acetate is the major short-chain fatty acid in fecal water of humans and animals and can be absorbed by the colon $(7,8)$. It can be found in the visceral-drained portal blood (intestines and spleen), and it enters the systemic circulation in measurable quantities in humans (9). In ruminants, acetate derived from the fermentation of carbohydrates provides a major source of energy

Received December 28, 1992; accepted April 23, 1993.

Correspondence: Carlos H. Lifschitz, M.D. Children's Nutrition Research Center, 1100 Bates, Houston, TX 77030

'This work is a publication of the USDA/ARS Children's Nutrition Research Center, Department of Pediatrics, Baylor College of Medicine and Texas Children`s Hospital, Houston, TX. This project has been supported in part by federal funds from the US. Department of Agriculture, Agricultural Research Service under Cooperative Agreement number 58-6250-1-003. The contents of this publication do not necessarily reflect the views or policies of the U.S. Department of Agriculture, nor does mention of trade names, commercial products, or organizations imply endorsement by the U.S. Government.
$(10,11)$. In nonruminants, although less is known about the systemic utilization of acetate, it is considered a potentially significant energy source $(12,13)$. Estimates indicate that up to $10 \%$ of the postabsorptive energy expenditure in humans could be derived from plasma acetate (14).

Acetate uptake and metabolism have been studied in a variety of animal species. The choice of species is important because not all monogastric species have the same capacity for fermentation; for example, dogs have high concentrations of short-chain fatty acids but low absolute quantities in contrast with humans and pigs, which have high concentrations and high quantities in the cecum and, therefore, high capacities for fermentation $(15,16)$. Because the development and function of the colon are similar in pigs and humans, we have studied the fate of acetate infused into the colon in infant pigs (17-19). The fecal flora of the infant pig, however, differs from that of the human infant, and because this difference might affect polysaccharide fermentation, we purposely avoided the infusion of polysaccharides and instead infused acetate, the most abundant of the short-chain fatty acids produced.

Circulating acetate can arise from both $\beta$-oxidation of tissue fatty acids and colonic fermentation of unabsorbed carbohydrate. In the present studies, we simultaneously infused piglets with $\left[{ }^{3} \mathrm{H}\right]$ acetate and $\left[{ }^{14} \mathrm{C}\right]$ acetate: $\left[{ }^{3} \mathrm{H}\right]$ Acetate was administered i.v. to label the circulating pool, whereas $\left[{ }^{14} \mathrm{C}\right]$ acetate was infused into the colon to label colon-derived acetate. The objectives of the experiment were to measure the baseline entry rate of acetate when the animal was in the postabsorptive state, to examine acetate concentration and specific radioactivity at different points in the circulation to identify potential sites of acetate utilization and synthesis, and to examine the efficiency with which colonic acetate is absorbed and utilized. Our findings suggested that baseline fermentation was maintained after an overnight fast, identified the gastrointestinal tract as an important site of acetate utilization in the fasted state, and showed that colonic acetate was efficiently absorbed and utilized by the infant pig.

\section{MATERIALS AND METHODS}

We studied six newborn contemporary Buckshire piglets, aged 2 to $6 \mathrm{~d}$; they were in good health and consuming amounts of feed appropriate for their age. All were delivered at term, and their wt ranged from 1.0 to $2.3 \mathrm{~kg}$, mean $\pm S E M 1.8 \pm 0.3 \mathrm{~kg}$. They were permitted to suckle for 6 to $8 \mathrm{~h}$, then weaned to a liquid sow-milk replacer (Soweena, Merrick's, Union Center, WI). The protocol was approved by the Baylor College of Medicine Animal Care Committee and care of the animals conformed to National Institutes of Health guidelines.

The pigs were fasted 8 to $12 \mathrm{~h}$ overnight, then sedated with an intramuscular injection of ketamine $(10 \mathrm{mg} / \mathrm{kg})$ and acepromazine (Aveco Co. Inc., Fort Dodge, IA) $(0.1 \mathrm{mg} / \mathrm{kg}$ ). Their tracheas were intubated, and the animals were anesthetized by administering isoflurane with a pediatric ventilator. Rectal temperatures 
were monitored, and stable body temperatures were maintained throughout the experiment by using an insulated heating pad placed beneath the animal and occasionally by using a heat lamp. The surgical procedure involved the placement of three radioopaque vascular catheters: one in the femoral artery, one in the femoral vein, and one threaded through the umbilical vein to the portal vein. Catheter placement was checked by intraoperative fluoroscopy, and in four animals portal vein placement was also confirmed by direct observation. Blood gases, electrolytes, glucose, blood urea nitrogen, and creatinine were monitored several times throughout the experiment.

A catheter was placed via a vesicotomy to monitor urine output. The ileum was surgically occluded at approximately 5 $\mathrm{cm}$ proximal to the ileocecal valve, and a catheter was threaded through an ileotomy into the bottom of the saccular cecum. Thus, backwash into the small intestine was prevented, and both outside air and the contents of the small intestine were excluded from the colon. The intestine was irrigated with a warm solution of $\mathrm{NaCl}$, and the surgical incisions were closed.

Acetate absorption. To label the total circulating pool of acetate derived both from endogenous production and exogenous uptake, a tracer of $\left[{ }^{3} \mathrm{H}\right]$ acetate was infused i.v. through the femoral vein throughout the 3-h experiment. For the last $2 \mathrm{~h}$, unlabeled acetate containing a tracer amount of $\left[{ }^{14} \mathrm{C}\right]$ acetate was infused into the cecum. Total fluid input was set at $200 \mathrm{~mL} \cdot \mathrm{kg}^{-1} \cdot \mathrm{d}^{-1}$. $\left[{ }^{3} \mathrm{H}\right]$ Acetate in $0.5 \mathrm{~mol} / \mathrm{L} \mathrm{NaCl}$ (NEN Research Products, Boston, MA) was infused at approximately $100 \mu \mathrm{Ci} \cdot \mathrm{kg}^{-1} \cdot \mathrm{h}^{-1}$. The $\mathrm{pH}$ of the saline solution was greater than 5.0 , well above the $\mathrm{pH}$ of acetate. The risk of evaporation therefore was negligible, which we confirmed during the pilot study by counting the radioactivity in an aliquot of the infusate. Steady-state isotopic enrichment of blood acetate occurred within 20 to $40 \mathrm{~min}$, and blood acetate levels were not perturbed by the tracer infusion. After $60 \mathrm{~min}$ of i.v. infusion, a second infusion was begun via the intracecal catheter and continued for $2 \mathrm{~h}$. The intracecal solution was sodium acetate (140 to $150 \mathrm{mM}$ ) in water (HPLC grade, Fisher Scientific, Pittsburgh, PA), pH adjusted to 6.5 with $\mathrm{NaOH}$, and tracer amounts of $\left[{ }^{14} \mathrm{C}\right]$ acetate (NEN Research Products, Boston, MA). A low intracecal infusion rate $\left(\leq 5 \mathrm{~mL} \cdot \mathrm{kg}^{-1} \cdot \mathrm{h}^{-1}\right)$ was set to avoid washing out the colon; infusion at this volume provided $1 \mathrm{mmol}$ acetate and $200 \mu \mathrm{Ci} \cdot \mathrm{kg}^{-1} \cdot \mathrm{h}^{-1}$. The amount of acetate was approximately equal to the total amount of short-chain fatty acid that would have been generated by the complete fermentation of $0.2 \mathrm{~g}$ of carbohydrate per $\mathrm{kg}$ of body weight over the $2-\mathrm{h}$ infusion.

As the $\left[{ }^{14} \mathrm{C}\right]$ acetate infusion was begun, the animal was connected to a small animal ventilator (Harvard Apparatus, South Natick, MA). Anesthesia was maintained by alternating intramuscular injections of ketamine $(15 \mathrm{mg} / \mathrm{kg})$ and acepromazine $(0.15 \mathrm{mg} / \mathrm{kg})$ with intramuscular injections of $0.075 \mathrm{~mL} / \mathrm{kg}$ InnovarVet (fentanyl $0.4 \mathrm{mg} / \mathrm{mL}$ plus droperidol $20 \mathrm{mg} / \mathrm{mL}$; Pitman-Moore, Washington Crossing, NJ). At the end of the experiment, the animals were killed by injecting an excess of the anesthetic drugs.

Paired blood samples were obtained from the femoral artery and portal vein for analysis of acetate concentration and radioactivity. During the first hour of the i.v. infusion of $\left[{ }^{3} \mathrm{H}\right]$ acetate, and before the intracecal infusion of $\left[{ }^{14} \mathrm{C}\right]$ acetate, the serum acetate values for femoral artery and portal vein remained constant (Fig. 1). In preliminary experiments, blood samples were obtained at baseline and every $20 \mathrm{~min}$ during the infusions. These experiments showed that steady-state isotope enrichment was achieved after a mean of $30 \mathrm{~min}$ of $\left[{ }^{3} \mathrm{H}\right]$ acetate infusion (Fig. 2 ); in later experiments, therefore, blood samples were taken before the $\left[{ }^{3} \mathrm{H}\right]$ acetate infusion and $60 \mathrm{~min}$, i.e. immediately before the intracecal infusion was begun (time 0 ), and every 15 min thereafter, for a total of 10 paired samples. (The femoral vein catheter was first used to obtain a baseline sample, then to infuse the $\left[{ }^{3} \mathrm{H}\right]$ acetate. Once it had been used for infusion, it was no longer used to collect blood samples.)

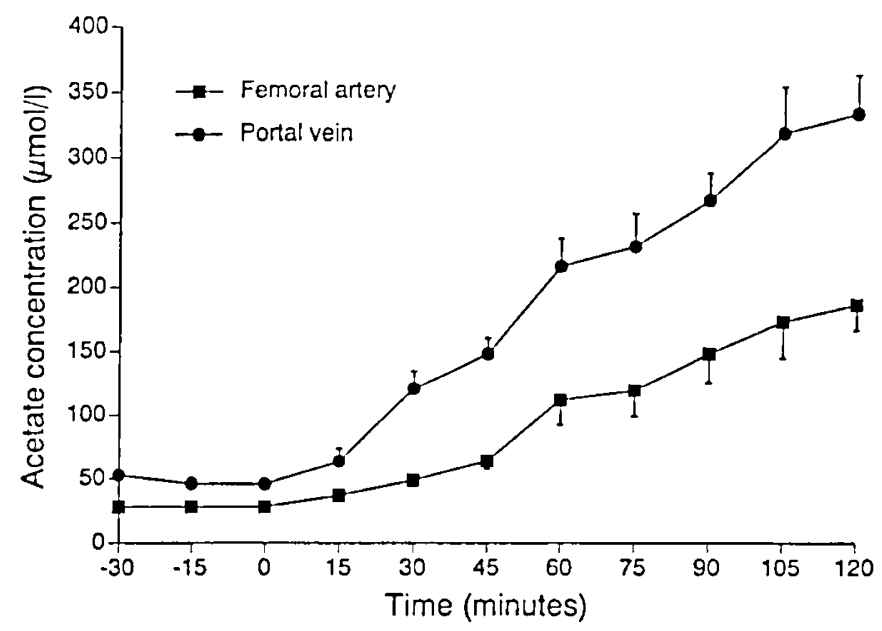

Fig. 1. Serum acetate concentrations in portal vein and femoral artery during the baseline period (shown are the 30 min preceding the initiation of the intracecal infusion) and during infusion of $1 \mathrm{mmol} \cdot \mathrm{kg}^{-1} \cdot \mathrm{h}^{-1}$ of acetate into the colon. The absolute difference between the portal vein and femoral artery values increased over the $2 \mathrm{~h}$ of infusion, but the percent difference remained the same, which indicated that extraction remained constant.

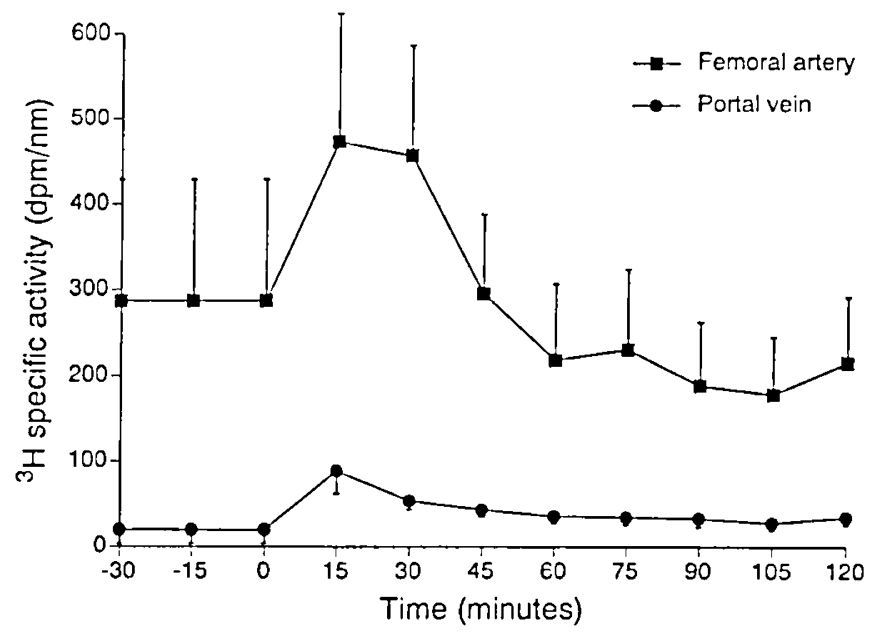

Fig. 2. Specific radioactivity of the i.v.-derived $\left[{ }^{3} \mathrm{H}\right]$ acetate in portal vein and femoral artery during the baseline period (shown are the 30 min preceding the initiation of the intracecal infusion) and during infusion of $1 \mathrm{mmol} \cdot \mathrm{kg}^{-1} \cdot \mathrm{h}^{-1}$ of acetate into the colon. Within $15 \mathrm{~min}$, the infusion of acetate into the colon disturbed the plateau that existed in the $\left[{ }^{3} \mathrm{H}\right]$ acetate specific radioactivity. $\left[{ }^{3} \mathrm{H}\right]$ Acetate specific radioactivity increased in both the femoral artery and portal vein before any increase in the acetate concentration in either vessel. After $45 \mathrm{~min}$, the $\left[{ }^{3} \mathrm{H}\right]$ acetate specific radioactivity decreased and in the femoral artery, it dropped below the preinfusion value.

Sample analysis. Serum samples were analyzed for acetate concentration by a modification of the HPLC method of Chen and Lifschitz (20), and radioactivity was determined using an on-line radioactivity detector. Briefly, the HPLC system (Waters Associates, Milford, MA) is made up of a cationic exchange column (ORH-801 Organic Acetates Column, Interaction Chemicals, Mountain View, CA) equipped with a conductivity detector connected to a dual-label radioactivity detector (FLOW 1/BETA, Radiomatic, Packard Instruments Co., Downers Grove, IL). By injecting serum to which we had added several other organic acids, we observed that the acetate peak did not coelute with any other peaks. The lowest limit of detection was $10 \mu \mathrm{mol} / \mathrm{L}$, and the coefficient of variation of replicate injections was lower than $5 \%$. To determine the efficiency of counts, the on-line detector 
was calibrated with standards of $\left[{ }^{3} \mathrm{H}\right]$ acetate and $\left[{ }^{14} \mathrm{C}\right]$ acetate containing known amounts of radioactivity and were counted both by the on-line detector and by a liquid scintillation counter (Mark III, model 6881, Analytical, Elk Grove, IL). Counting efficiency of the on-line detector was $50 \%$ for ${ }^{3} \mathrm{H}$ and $93 \%$ for ${ }^{14} \mathrm{C}$. The ratios of ${ }^{3} \mathrm{H}:{ }^{14} \mathrm{C}$ remained constant at different concentrations of standards. Serum with an internal standard (isovalerate) was ultrafiltered (Ultrafree-MC, Millipore, Bedford, MA). Acetate (Alltech, Deerfield, IL), radioisotope standards $\left({ }^{3} \mathrm{H}\right]$ acetate, $\left[{ }^{14} \mathrm{C}\right]$ acetate, $\left[{ }^{14} \mathrm{C}\right]$ sodium bicarbonate; NEN Research Products), and serum samples were injected into the HPLC. radioactive detector system. Acetate was expressed as $\mu \mathrm{mol} / \mathrm{L}$, and radioactivity as dpm.

Recovery experiments were performed using plasma with a measured acetate concentration of $73.2 \mu \mathrm{mol} / \mathrm{L}$. The plasma was then spiked with acetate standards in amounts of $31.25,62.5$, $125,250,500,1000$, and $2000 \mu \mathrm{mol} / \mathrm{L}$. Recoveries of spiked acetate were $96.9 \%, 101 \%, 102 \%, 97.8 \%, 91.7 \%, 105 \%$, and $98.3 \%$, respectively, with a mean recovery of $98.9 \pm 4.25 \%$ over a 64-fold concentration range.

Blood gases and electrolytes were analyzed by a clinical chemistry laboratory. Osmolality was measured by freezing depression using a vapor pressure osmometer (Wescor, Inc., Logan, UT).

Calculations. The specific radioactivity $(\mathrm{SR})$ of $\left[{ }^{3} \mathrm{H}\right]$ acetate in the femoral artery $(\mathrm{dpm} / \mu \mathrm{mol})$ was used to calculate the entry rate $(E R)$ of acetate by the equation:

ER $(\mu \mathrm{mol} / \mathrm{min})=[($ i.v. tracer infusion rate

$$
\mathrm{dpm} / \mathrm{min}) /(\text { arterial SR } \mathrm{dpm} / \mu \mathrm{mol})]
$$

Results were normalized to $\mathrm{kg}$ of body weight. The extraction coefficient of the portal-drained viscera (intestines, pancreas, and spleen) was calculated from $\left[{ }^{3} \mathrm{H}\right]$ acetate data using the following equation:

$$
[(\mathrm{dpm} / \mathrm{mL}) \mathrm{art}-(\mathrm{dpm} / \mathrm{mL}) \mathrm{pv}] /(\mathrm{dpm} / \mathrm{mL}) \mathrm{art} \cdot 100
$$

where art is the femoral artery and pv is the portal vein.

Data analysis. The acetate values obtained from each sampling site were compared with each other at the different sampling times by paired $t$ test. All results are expressed as means and SEM. Groups were compared with respect to change over time by fitting second-degree polynomials to the sequence of data points for femoral artery and/or portal vein from each subject. The coefficients from these regressions, which summarize the time trend for each individual, were then used to compare artery with vein by application of a paired $t$ test.

\section{RESULTS}

Baseline. The concentration of circulating acetate was low in the fasting state, and a concentration gradient was observed between the different sampling sites. The mean \pm SEM of acetate concentration was $17 \pm 1 \mu \mathrm{mol} / \mathrm{L}$ in peripheral venous blood, $28.2 \pm 4.1 \mu \mathrm{mol} / \mathrm{L}$ in femoral arterial blood, and $45.8 \pm 4.4$ $\mu \mathrm{mol} / \mathrm{L}$ in portal venous blood, a gradient that implies one of two possibilities: 1 ) the liver neither utilizes nor releases acetate and the gradient is a result of dilution by venous blood draining a variety of tissues with low acetate concentration, or 2) acetate is utilized in the fasting state by both the liver and peripheral tissues.

Before the cecal infusion of acetate was begun, total radioactivity $\left(\left[{ }^{3} \mathrm{H}\right]\right.$ acetate specific radioactivity $\times$ acetate concentration) was lower in the portal vein than in the femoral artery, which suggests that the portal-drained viscera utilized some of the acetate (Table 1).

Acetate Infusion into Colon. During the acetate infusion into the colon, blood acetate levels increased, with a substantial rise in the mean femoral artery concentration to a maximum of 186 $\pm 20 \mu \mathrm{mol} / \mathrm{L}$ (Fig. 1, Table 1). A much higher rise in mean acetate concentration was observed in the portal vein, up to seven times the baseline value, with a maximum of $333 \pm 31$ $\mu \mathrm{mol} / \mathrm{L}(p<0.001)$ (Fig. 1, Table 1). The arteriovenous concentration difference noted at baseline persisted throughout the experiment in all animals. The absolute difference between values from the portal vein and the femoral artery increased over the $2 \mathrm{~h}$ of the infusion (from $17.7 \pm 4.6 \mu \mathrm{mol} / \mathrm{L}$ at baseline to $147 \pm 18 \mu \mathrm{mol} / \mathrm{L}$ at $120 \mathrm{~min}$ ), but the difference in percentage changed only from $76.7 \pm 24 \%$ at baseline to $82.7 \pm 15 \%$ at 120 $\min$.

Isotopic Labeling of Circulating Pools. $\left[{ }^{14} \mathrm{C}\right]$ Acetate derived from colon. The specific radioactivity of $\left[{ }^{14} \mathrm{C}\right]$ acetate in portal venous blood rose quickly during the cecal infusion of ${ }^{14} \mathrm{C}$-labeled acetate; the specific radioactivity in femoral arterial blood rose more slowly (Fig. 3). A trend analysis revealed that these patterns were significantly different from each other $(p<0.05)$. By the end of the infusion, specific radioactivity was the same in artery and vein, and was equal to the specific radioactivity of the acetate infused into the cecum (Table 1).

$l^{3}$ H]Acetate infused i.v. The $\left[{ }^{3} \mathrm{H}\right]$ acetate specific radioactivity plateaued in the basal state, after which the infusion of acetate into the colon was begun; within $15 \mathrm{~min}$ the plateau was disturbed by a significant increase in the specific radioactivity of $\left[{ }^{3} \mathrm{H}\right]$ acetate in both the femoral artery $(p=0.006)$ and the portal vein $(p=0.025)$ (Fig. 2). This increase occurred before the acetate concentration had risen substantially in either artery or vein (Fig. 1). After $45 \mathrm{~min}$, the $\left[{ }^{3} \mathrm{H}\right]$ acetate specific radioactivity decreased in both artery and vein; it decreased in the femoral artery to a value below the preinfusion value. The $\left[{ }^{3} \mathrm{H}\right]$ acetate specific radioactivity at $60 \mathrm{~min}$ was significantly lower than the 15 -min value in both the femoral artery $(p=0.03)$ and portal vein $(p=0.038)$.

Our most unexpected finding was the substantial difference in the specific radioactivity of $\left[{ }^{3} \mathrm{H}\right]$ acetate between the portal vein and the femoral artery at the end of the colonic infusion. Although the portal vein acetate concentration at the end of the intracolonic infusion was $64 \%$ higher than in the fasted state, the portal vein specific radioactivity was $86 \%$ lower. Thus, the utilization of acetate by the portal-drained viscera in the fasted state persisted throughout the intracecal infusion of acetate (Table 2); as increasing amounts of acetate were infused into the colon and entered the circulation, increasing amounts of acetate were utilized by the viscera.

The uptake of acetate into the colon increased the entry rate at $120 \mathrm{~min}$ to $28 \pm 8.7 \mu \mathrm{mol} \cdot \mathrm{kg}^{-1} \cdot \mathrm{min}^{-1}\left(1.68 \mathrm{mmol} \cdot \mathrm{kg}^{-1} \cdot \mathrm{h}^{-1}\right)$, a value that was not statistically different from the rate of infusion of approximately $1 \mathrm{mmol} \cdot \mathrm{kg}^{-1} \cdot \mathrm{h}^{-1}$ (Table 2); an increment in the entry rate of approximately $60 \%$ of the infusion rate. The rate of infusion of $\left[{ }^{14} \mathrm{C}\right]$ acetate into the colon was twice that of the i.v. infusion of $\left[{ }^{3} \mathrm{H}\right]$ acetate into the femoral vein, but the mean ratio of ${ }^{14} \mathrm{C}:{ }^{3} \mathrm{H}$ was $1.39( \pm 0.4)$.

\section{DISCUSSION}

A considerable amount of fermentation occurs in the human colon $(1,9)$. Short-chain fatty acids are the principal anions in feces, and acetate, the major short-chain fatty acid, can be absorbed by the colon $(7,8)$.

The capacity of human newborns to digest lactose in the small intestine is limited, and only $30-60 \%$ of the lactose they ingest may reach the colon where it can be fermented into short-chain fatty acids (21-24). Therefore, even though an infant consumes no fiber as such, a considerable amount of carbohydrate fermentation occurs. We postulated that acetate absorbed in the colon could be an important secondary nutrient source for infants, particularly preterm infants $(23,24)$ and those with malabsorption or chronic diarrhea (25). This hypothesis has been supported in studies of Kien et al. (24) who estimated that the mean entry rate of acetic acid in premature infants is $63.7 \mu \mathrm{mol} \cdot \mathrm{kg}^{-1} \cdot \mathrm{min}^{-1}$. We also have observed substantial increases in serum acetate 
Table 1. Acetate concentration. $/^{3}$ HJacetate $S R$, and $/{ }^{14}$ Clacetate $S R$ before time 0 and after 2 h of intracecal infusion of acetate*

\begin{tabular}{|c|c|c|c|c|c|c|}
\hline & \multicolumn{3}{|c|}{ Time 0} & \multicolumn{3}{|c|}{ 2-h Infusion } \\
\hline & $\begin{array}{c}\text { Concentration, } \\
\mu \mathrm{mol} / \mathrm{L}\end{array}$ & $\begin{array}{c}{\left[{ }^{3} \mathrm{H}\right] \mathrm{SR},} \\
\mathrm{dpm} / \\
\mu \mathrm{mol}\end{array}$ & $\begin{array}{c}{\left[{ }^{14} \mathrm{C}\right] \mathrm{SR},} \\
\mathrm{dpm} / \\
\mu \mathrm{mol}\end{array}$ & $\begin{array}{l}\text { Concentration. } \\
\mu \mathrm{mol} / \mathrm{L}\end{array}$ & $\begin{array}{c}{\left[{ }^{3} \mathrm{H}\right] \mathrm{SR},} \\
\mathrm{dpm} / \\
\mu \mathrm{mol}\end{array}$ & $\begin{array}{c}{\left[{ }^{14} \mathrm{C}\right] \mathrm{SR}} \\
\mathrm{dpm} / \\
\mu \mathrm{mol}\end{array}$ \\
\hline Portal vein & $46(4)$ & $20(16)$ & 0 & $333(31)$ & $34(9)$ & $188(11)$ \\
\hline Femoral artery & $28(4) \dagger$ & $287(142)$ & 0 & $186(20) \ddagger$ & $216(76) \dagger$ & $189(14)$ \\
\hline
\end{tabular}

* Results are means $( \pm \mathrm{SEM})$. SR, specific radioactivity.

$+p<0.05$.

$\ddagger p<0.001$.

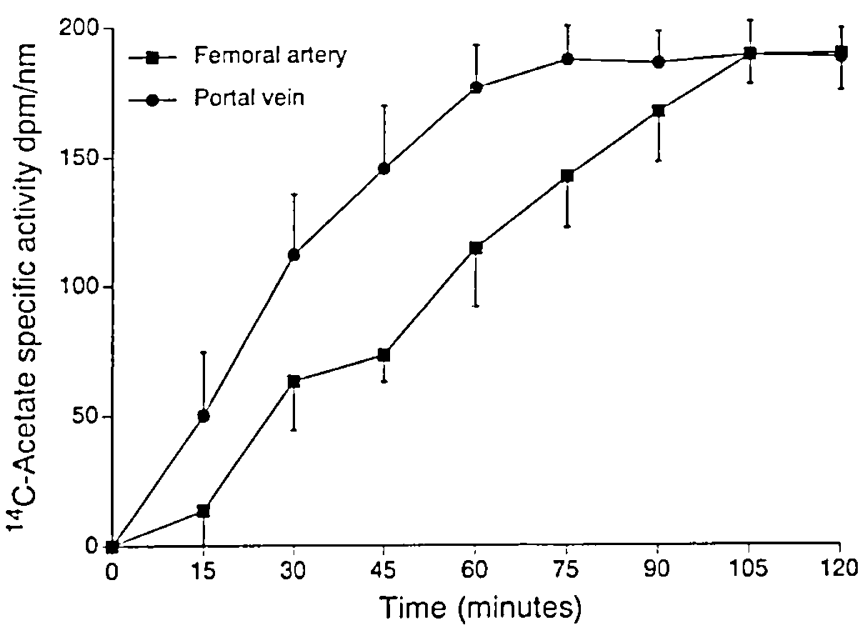

Fig. 3. Specific radioactivity of $\left[{ }^{14} \mathrm{C}\right] \mathrm{acetate}$ in blood during the cecal infusion of $1 \mathrm{mmol}$ acetate $\cdot \mathrm{kg}^{-1} \cdot \mathrm{h}^{-1}$. The specific radioactivity in the portal vein increased quickly, followed more slowly by the specific radioactivity in the femoral artery. By the end of the infusion, the specific radioactivity in artery and vein were the same, and both were equal to the specific radioactivity of the acetate infused into the cecum.

Table 2. Rate at which acetate entered circulation and percentage of extraction (clearance) of acetate from arterial circulation by gut immediately before time 0 and after $2 \mathrm{~h}$ of intracecal infusion of acetate at $16.7 \mu \mathrm{mol} \cdot \mathrm{kg}^{-1} \cdot \mathrm{min}^{-1 *}$

\begin{tabular}{ccc} 
& $\begin{array}{c}\text { Entry rate, } \\
\mu \mathrm{mol} .\end{array}$ \\
$\begin{array}{c}\text { Time of } \\
\mathrm{kg}^{-1} . \\
\mathrm{min}^{-1}\end{array}$ & $\begin{array}{c}\text { Extraction, } \\
\%\end{array}$ \\
\hline infusion & $18.3(4.9)$ & $89(7)$ \\
$2 \mathrm{~h}$ & $28.0(8.7)$ & $68(6)$ \\
\hline
\end{tabular}

* Results are means $( \pm$ SEM).

levels in infants with malnutrition in whom glucose had been infused into the cecum (8).

Because the development and function of the colon are similar in pigs and humans $(17-19,26,27)$, we examined acetate metabolism in infant pigs, specifically the absorptive efficiency of colonic acetate. In most studies of acetate utilization, however, the colon is cleansed of fecal material before the infusion. To approximate a normal colonic environment, we chose not to cleanse the colon. Our choice, however, may have complicated the kinetic interpretation of the data, because some of the infusate may have been absorbed by the feces initially and only later released into the lumen. Although the basal serum acetate concentrations in the neonatal pigs were lower than acetate concentrations reported previously in older animals (28), they were within quantifiable levels. The difference in concentration apparently did not reflect a methodologic difference because our determinations of acetate concentrations in peripheral blood of adult humans, both fasting and after ingesting acetate, were similar to values in the literature (fasting $53.8 \pm 4.4 \mu \mathrm{mol} / \mathrm{L})(1$,
9, 29). The lower acetate blood levels that we report are presumably a result of the younger age of the animals we studied ( 1 to $6 \mathrm{~d}$ ) and possibly reflect the low fat stores (and hence fatty acid utilization) of the infant pig (19), in addition to a lower contribution of acetate by the colon $(26,27)$. It is possible, however, that our experimental design produced artifacts based on the potential antilipolytic effects of the anesthetics used during the perfusion.

Despite the lower absolute values observed in our study, a measurable gradient of acetate concentration from the femoral artery to the portal vein was observed; such a concentration gradient has been found previously in older pigs and in humans $(28,29)$. The existence of such a gradient suggests that as early as $1 \mathrm{~d}$ after birth, active colonic fermentation provides enough acetate to the portal vein to maintain an arteriovenous difference. It is possible that the acetate resulted directly from fatty acid metabolism in gastrointestinal tissues (30). These findings in pigs are similar to the developmental characteristics of human infants. Fecal short-chain fatty acid concentrations are lower in young infants than in older children or adults, despite the relatively large amounts of lactose that arrive in the colon of young infants, particularly those born prematurely $(22,23,31)$.

As expected, $\left[{ }^{14} \mathrm{C}\right]$ acetate infused into the colon appeared in the portal vein and entered the systemic circulation. At the end of the experiment when we found that $\left[{ }^{14} \mathrm{C}\right]$ acetate specific radioactivity was similar to specific activity in the femoral vein, we concluded that virtually all circulating acetate was derived from the colon and virtually all acetate administered had been absorbed. The use of i.v. infused $\left[{ }^{3} \mathrm{H}\right]$ acetate provided a separate measure of acetate entry rate and enabled a comparison with the rate of colonically infused tracee acetate. A steady state, however, was achieved only toward the end of the experimental period. The delay in achieving a steady state could have resulted from uneven absorption of acetate by the bowel. In addition, because the bowel was not cleansed of fecal material before the infusion, acetate may have been first absorbed by the fecal material, which would have delayed absorption by the bowel itself. Acetate was not produced by peripheral tissues during our study, as evidenced by the plateau in femoral artery specific radioactivity (Fig. 3).

Few data exist regarding the amount of acetate available from colonic fermentation in nonruminants. Cummings and Branch (32) extrapolated data about ruminants and estimated that adult humans eating a typical British diet daily consume $20 \mathrm{~g}$ of substrate available for colonic fermentation; from that amount, $200 \mathrm{mmol}$ are produced and 7 to $20 \mathrm{mmol}$ are excreted in the feces. In our study, the acetate was infused at a normal molality, and the total dose was approximately the same amount of acetate produced by $2 \%$ of the carbohydrate ingested at one feeding by a formula-fed infant during the first month of life $(130 \mathrm{~mL})$. We observed no perturbations of blood gases or serum electrolytes and no apparent plateau in uptake or utilization of acetate.

Our studies also demonstrated that when acetate was infused into the colon and before blood levels rose significantly, endogenous production of acetate declined. That decline could have indicated the existence of a sensitive balance between the colonic uptake and the endogenous production of acetate.

Although the sources of acetate in the postabsorptive state are 
not identifiable in this study, hepatic production seems likely, and hepatic acetate production is sensitive to circulating acetate concentration. Others have observed in adult rats that $200 \mu \mathrm{mol} /$ $\mathrm{L}$ of acetate in blood appears to be the threshold: When the acetate concentration in portal blood falls below that level, the liver produces acetate (12). However, our results imply that the threshold concentration in neonatal pigs may be lower. Although the phenomenon varied considerably from animal to animal as acetate concentration rose in the portal vein, the entry rate also rose to as much as 6-fold above baseline.

The concentration of acetate was higher in the portal vein than in the femoral artery; therefore, the liver (and perhaps lung, heart, or both) must have consumed a significant amount of acetate. Although we have not quantified the hepatic extraction of acetate, Bleiberg $e t$ al. (30) have suggested that hepatic extraction of acetate does occur in dogs. Acetate metabolism by the liver is variable, species-specific, and depends on numerous factors; for example, acetate uptake is low in the ruminant liver but is believed to be much greater in humans, perhaps because the human liver is capable of lipogenesis $(12,32)$. In rats and pigs, acetate is taken up by the liver in proportion to the acetate concentration in the portal vein $(12,28,33)$.

At the end of the intracolonic infusion, the entry rate of acetate into the peripheral circulation was $1.68 \mathrm{mmol} \cdot \mathrm{kg}^{-1} \cdot \mathrm{h}^{-1}$, a value that was not statistically different from the rate of infusion (approximately $1 \mathrm{mmol} \cdot \mathrm{kg}^{-1} \cdot \mathrm{h}^{-1}$ ). Again, this discrepancy can be explained in several ways. We observed a relatively large interindividual variability between animals that could have been the result of uneven absorption of acetate by the bowel because of early absorption and delayed release of acetate by the fecal material in the bowel (which varied greatly between animals). The variability also may have resulted from an uneven flow of acetate caused by the low infusion rate and the compliance of the colon.

Some investigators have reported that $50 \%$ of the intraluminal colonic acetate in pigs is directly metabolized by the epithelium, whereas a lesser proportion is metabolized by the gut from circulating acetate (28). In contrast, we have shown that a large proportion of the infused acetate was taken up into the systemic circulation and was accompanied by a significant consumption of arterial acetate by the portal-drained viscera. This circumstance has been also reported in ruminants, in which $25-35 \%$ of arterial acetate is removed as it passes through the gut (12). Bleiberg et al. (30) recently demonstrated substantial clearance of arterial acetate by the gut in dogs, in which the values for extraction were similar to those for the pigs in our study. After acetate had been infused into the colon, we calculated the amount that reached the peripheral circulation from the ratio of ${ }^{14} \mathrm{C}:{ }^{3} \mathrm{H}$ in the femoral artery. The rate of $\left[{ }^{14} \mathrm{C}\right]$ acetate infusion into the colon was twice that of the $\left[{ }^{3} \mathrm{H}\right]$ acetate infusion into the femoral vein; thus, one would expect a $2: 1$ ratio of ${ }^{14} \mathrm{C}:{ }^{3} \mathrm{H}$ if all acetate infused into the colon reached the peripheral circulation. However, the mean ratio was $1.39( \pm 0.4)$, which suggests that a mean of $71 \%( \pm 21 \%)$ of the acetate infused into the colon bypassed the liver and entered the peripheral circulation.

In summary, the neonatal pig demonstrates both efficient uptake of acetate from the colonic lumen and systemic utilization of that acetate. The presence of exogenous acetate appears to regulate the production of endogenous acetate via a mechanism more complex than the simple relationship between circulating acetate concentrations. If these findings are also true in humans, the acetate that results from colonic carbohydrate fermentation may provide a significant source of energy for the human infant.

\section{REFERENCES}

1. Cummings JH, Englyst HN 1987 Fermentation in the human large intestine and the available substrates. Am J Clin Nutr 45:1243-1245

2. Roediger WEW, Moore A 1981 Effect of short chain fatty acids in sodium absorption in isolated human colon perfused through the vascular bed. Dig Dis Sci 26:100-106

3. Roediger WEW 1980 Role of anaerobic bacteria in the metabolic welfare of the colonic mucosa in man. Gut 21:793-798

4. Roediger WEW 1982 Utilization of nutrients by isolated epithelial cells of the rat colon. Gastroenterology 83:424-42y

5. Harig JM, Soergel KH, Komorowski RA, Wood CM 1989 Treatment of diversion colitis with short-chain-fatty acid irrigation. N Engl J Med 320:23-28

6. Koruda MG, Rolandelli RH. Settle RG. Zimmaro DM, Rombeau JL 1988 Effect of parental nutrition supplemented with short-chain fatty acids on adaptation to massive small bowel resection. Gastroenterology 95:715-720

7. McNeil NI, Cummings JH, James WPT 1978 Short chain fatty acid absorption by the human large intestine. Gut 19:819-822

8. Lifschitz CH, Carrazza F. Klein PD. Reeds PJ 1991 Contribution of fermented carbohydrate to circulating acetate in infants with and without diarrhea. Gastroenterology 100:A530(abstr)

9. Pomare EW, Branch WJ, Cummings JH 1985 Carbohydrate fermentation in the human colon and its relationship to acetate concentrations in venous blood. J Clin Invest 75:1448-1454

10. Sabine JR, Johnson BC 1964 Acetate metabolism in the ruminant. J Biol Chem 239:89-94

11. Bergman EN, Wolff JE 1971 Metabolism of volatile fatty acids by liver and portal-drained viscera in sheep. Am J Physiol 221:586-592

12. Bergman EN 1990 Energy contributions of volatile fatty acids from the gastrointestinal tract in various species. Physiol Rev 70:567-590

13. Argenzio RA 1982 Volatile fatty acid production and absorption from the large intestine of the pig. In: Laplace JP. Corring T, Rerat A (eds) Digestive Physiology in the Pig. Second International Seminar, Institut National de la Recherche Agronomique, Paris, pp 207-215

14. Skutches CL, Holyroyde CP, Myers RN, Paul P. Reichard GA 1979 Plasma acetate turnover and oxidation. J Clin Invest 64:708-713

15. Banta CA, Clemens ET, Krinsky MM, Sheffy BE 1979 Sites of organic acid production and patterns of digesta movement in the gastrointestinal tract of dogs. J Nutr 109:1592-1600

16. Buffington CA 1984 Comparative digestion and absorption in domestic animals. In: Phillips RW (ed) Animal Models for Nutrition Research. Report of the Fifth Ross Conference on Medical Research. Ross Laboratories, Columbus, $\mathrm{OH}$, pp 2-5

17. Fleming SE, Arce D 1986 Using the pig to study digestion and fermentation in the gut. In: Tumblesome ME (ed) Swine in Biomedical Research. Plenum, New York, pp 123-134

18. Shulman RJ, Henning SJ, Nichols BL 1988 The miniature pig as an animal model for the study of intestinal enzyme development. Pediatr Res 23:311315

19. Pond WG, Haupt KA 1978 The pig as a model in biomedical research. In Pond WG. Haupt KA (eds) The Biology of the Pig. Cornell University Press. Ithaca, NY pp 40-41

20. Chen H-M, Lifschitz CH 1989 Preparation of fecal samples for assay of volatile fatty acids by gas-liquid chromatography and high-performance liquid chromatography. Clin Chem 35:74-76

21. Lebenthal E, Hatch TF. Lee PC 1981 Development of disaccharidases in premature, small-for-gestational age and full-term infants. In: Lebenthal $E$ (ed) Textbook of Gastroenterology and Nutrition in Infancy, Volume 1: Gastrointestinal Development and Perinatal Nutrition. Raven, New York. pp 413-422

22. Lifschitz CH. Smith EO, Garza C 1983 Delayed complete functional lactase sufficiency in breast-fed infants. J Pediatr Gastroenterol Nutr 2:478-482

23. MacLean Jr W, Fink B 1980 Lactose malabsorption by premature infants: magnitude and clinical significance. J Pediatr 97:383-388

24. Kien CL. Kepner J, Grotjohn K, Ault K. McClead RE 1992 Stable isotope model for estimating colonic acetate production in premature infants. Gastroenterology 102:1458-1466

25. Lifschitz $\mathrm{CH}$, Irving CS, Gopalakrishna GS, Evans K, Nichols BL 1983 Carbohydrate malabsorption in infants with diarrhea studied with the breath hydrogen test. J Pediatr 102:371-375

26. Murray RD, McClung HJ, Li BUK, Ailabouni A 1987 Short-chain fatty acid profile in the colon of newborn piglets using fecal water analysis. Pediatr Res 22:720-724

27. Argenzio RA, Moon HW, Kemeny LJ, Whipp SC 1984 Colonic compensation in transmissible gastroenteritis of swine. Gastroenterology 86:1501-1509

28. Imoto S, Namioka S 1978 VFA metabolism in the pig. J Anim Sci 47:479_ 487

29. Cummings JH, Pomare EW, Branch WJ, Naylor CPE, Macfarlane GT 1987 Short chain fatty acids in human large intestine, portal, hepatic and venous blood. Gut 28:1221-1227

30. Bleiberg B, Beers TR, Persson M, Miles JM 1992 Systemic and regional acetate kinetics in dogs. Am J Physiol 262:E197-E201

31. Lifschitz CH, Wolin MJ, Reeds PJ 1990 Characterization of carbohydrate fermentation in feces of formula-fed and breast-fed infants. Pediatr Res 27:165-169

32. Cummings JH, Branch WJ 1986 Fermentation and production of short chain fatty acids in the human large intestine. In: Vahouny GV, Kritchevsky D (eds) Dietary Fiber, Basic and Clinical Aspects. Proceedings of the Second Washington Symposium on Dietary Fiber. Plenum, New York, pp 131-134

33. Demigné C, Yacoub C, Rémésy C 1986 Effects of absorption of volatile fatty acids on rat liver metabolism. J Nutr 11:77-86 